Jaska E., Werenowska A., The use of social media in communication and branding, „Economics and Law", Polszakiewicz B., Boehlke J. (ed.), Vol. 13, No. 1/2014, pp. 47-58. DOI: http://dx.doi. org/10.12775/EiP.2014.004.

\author{
EWA JASKA ${ }^{*}$, AgNIESZKA WerenOWSKA ${ }^{* *}$
}

\title{
THE USE OF SOCIAL MEDIA IN COMMUNICATION AND BRANDING
}

\author{
SUMMARY
}

Searching for information on products and services combined with the growing interest in social media make them important channels of marketing communication and more and more companies see their advertising potential. In order to demonstrate the role of social media in shaping the corporate image and branding the paper discusses the reasons for companies' interest in this form of communication, its application in the internal communication system as well as the benefits and risks of a brand engagement in social media. According to the research presented in the literature and our own study social marketing has become an important and desirable channel for image building and brand promotion.

Keywords: social media, marketing communication, internal communication, brand communication

JEL Classification: M31, M37

" Ewa Jaska, Warsaw University of Life Sciences, Faculty of Economics, Department of Economics of Education, Communication and Consulting, ul. Nowourysnowska 166, 02-787 Warszawa, phone: +48 607777 733, e-mail: ewa_jaska@sggw.pl (corresponding author).

Agnieszka Werenowska, Warsaw University of Life Sciences, Faculty of Economics, Department of Economics of Education, Communication and Consulting, ul. Nowourysnowska 166, 02-787 Warszawa, phone: +48 664198 540, e-mail: agnieszka_werenowska@sggw.pl. 


\section{INTRODUCTION}

In recent years, social networking has become a marketing tool for entrepreneurs, offering better access to potential clients and groups and is no longer considered merely a communication center for young people. Nowadays, when searching for the latest news, people more often reach for interactive rather than traditional media. In the past, companies could communicate with their customers via TV, radio, billboards and printed materials. Currently, there has been a shift in marketing tactics from supplying customers with products and services to engaging them in a dialogue and this is what social media are meant for.

The aim of this paper is to explore the role of social media in shaping a company's image and brand promotion. The formulation of the objective includes an assumption that the strategy of the company's engagement in social media comprises a specific plan and deliberate efforts aimed at achieving the assumed and measurable results. The lack of such a strategy, or failure in its adjustment to the overall policy of the organization, may reduce the potential business benefits offered by new communication channels, as costs rise and the risk of mistakes increases. This study presents both the results of our own research and the results of research from the literature of the subject.

\section{REASONS FOR COMPANIES' INTEREST IN SOCIAL MEDIA}

From the point of view of marketing: "social media is a channel of communication, which, in contrast to the traditional channels (e.g. TV, radio, newspapers), where the message is transmitted only in one direction - to the client, provides two-way communication. In other words, it is not only what we say to the client, but also what the client says to us. Perhaps the latter is even more important"1.

Using these channels, users can keep in touch, upload and share different content. In order to know the expectations of consumers for companies in 2008 IMAS International conducted a survey commissioned by Euro RSCG

${ }^{1}$ M. Grzechowiak, Internet Standard. Social Media 2010, International Data Group Poland SA, Warszawa 2010, p. 4. 
Sensors ${ }^{2}$. More than half of Poles declared that they are more and more interested in corporate activities and corporate brand image. The report "The Future of the Corporate Brand" formulates five principles that are meant to serve as guidelines for corporations. They include the principle directly relating to the role of public opinion "(...) respect the power of consumers. As many as $80 \%$ of respondents in Poland believe that companies should be more guided by public opinion in determining their overall strategy"3.

The report highlights the fact that Polish consumers expect more openness and dialogue with the brand. Social media is an excellent tool for this type of communication. In addition, the increased interest on the part of advertisers had a huge impact on the development of online advertising opportunities. Apart from the speed with which companies can implement their marketing strategies, they get access to unique and creative advertising solutions ${ }^{4}$.

Another advantage of this type of marketing is a network monitoring. It allows one to collect important information about what Internet users think about the brand and how they perceive its products and services. "Social networks are also a valuable source of industry information, which provide information about the trends and directions of branch development and data for competitive analysis. Monitoring of the network discussions enables understanding of the needs and expectations of consumers" 5 .

Joining social channels allows the company to provide reliable information about products and services, as well as initiate two-way communication building customer relations and trust in the brand. To achieve this, it is necessary to regularly update information about events and new products, support customer service department, organize competitions and promotions as well as use social networks to recruit new customers or employees. "Nearly three quarters of respondents in Gemius study declared that they search for opinions about brands and products before making the final decision on whether to purchase the goods. By engaging this group in a dialogue, the company acquires brand ambassadors. And they become prosumers, or active consumers, who are a source of inspiration and ratings for most Internet users"6.

${ }^{2}$ Proto.pl, Przysztość marki korporacyjnej, http://www.proto.pl (01.05.2012).

3 Ibidem.

${ }^{4}$ A. Sakowicz, A. Kawecki, Cyfrowo i szybko w reklamie, „Marketing w praktyce”, Nr 1/2011, p. 7.

${ }^{5}$ E. Majewski, Social media zmieniaja biznes, „Nowoczesne zarządzanie”, Nr 1/2010.

${ }^{6}$ Ibidem, p. 34. 


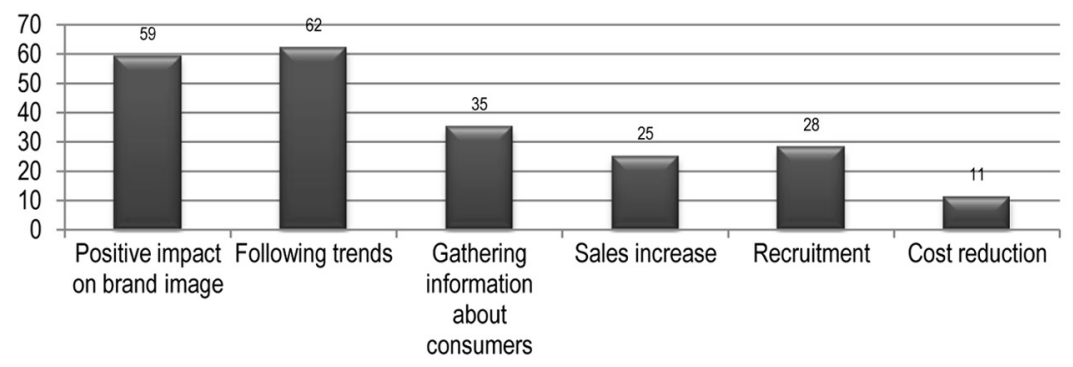

Figure 1. Reasons for engagement in social media [\%]

* Respondents could select one or several answers.

Source: Deloitte, Biznes społecznościowy - nowa era w komunikacji biznesowej, Warszawa 2012, p. 10.

The findings of the research conducted by Deloitte show that the main objective of a brand engagement in social media is the positive influence on the brand image (59\%), and tracking current trends in the market (62\%). It can therefore be assumed that the owners and managers of Polish companies still do not know all the possibilities and the potential of social media channels. „In particular, the benefits for recruiters (HR departments) appear to be undervalued. Only $28 \%$ of companies admitted that they use social media for recruitment. The potential of social network in this area is considerable - it is the image content carrier, a tool for the verification of the candidate's competence and an interactive platform to build long-lasting, deeper relationships with the community gathered around the company"7.

\section{INTERNAL COMMUNICATION AND SOCIAL MEDIA}

The owners and managers of large companies quickly recognized the potential of social media. Now, more and more small businesses appreciate the possibilities provided by these channels of communication. Managers of different levels, rather than giving orders by email and phone, are just beginning to use social networking sites. An innovative approach to communication with employees or business partners pays back with instant feedback, which is regarded as one of the determinants of good economic performance and reduces corporate distance. However, past research show that half of the companies

${ }^{7}$ Deloitte, Biznes spotecznościowy - nowa era w komunikacji biznesowej, Warszawa 2012, p. 10. 
operating in Polish market do not use social media for internal communication and the most frequently given reason is the lack of needs in this respect ${ }^{8}$.

The majority of companies using social media for communicating within the organization are large business players employing over 1,000 employees. The main reasons given for the implementation of this type of communication were to improve communication and create a new information channel, to strengthen the relations between employees and enhance identification with the company. "Companies that are already using social media for internal communication are twice as likely to declare the willingness to develop these solutions. Such opinion was expressed by $67 \%$ of respondents. Among the companies that have not implemented social media for internal communication, $69 \%$ do not plan to do so in the near future" (figure 2.).

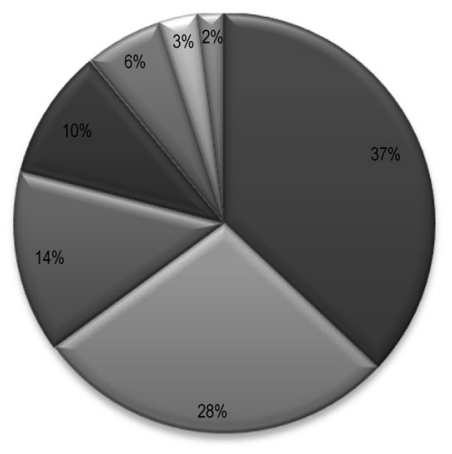

- Improving communication

$\square$ Information transfer

- Speeding communication

Enhancing relationships

between employees

$\checkmark$ Source of ideas and opinions

ఐ Enhancing employees'

engagement

Figure 2. Objectives of social media implementation for communication within a company [\%]

Source: Socialpress.pl, Social media w firmach usprawniają komunikacje i budują relacje miedzy pracownikami, http:// socialpress.pl (13.01.2012).

Communication within an organization with relying on social media enhances positive relationships between workers and management. The company is more resistant to staff crises and its employees become a source of inspiration. „Internal portals enable monitoring of the employee attitudes by looking at the posts on forums and drawing from the knowledge and creativity of employees (....). Such solutions reduce the amount of so-called „toxic commu-

\footnotetext{
${ }^{8}$ RR Communication Consulting, http://www.rrcc.pl (08.06.2013).

9 Socialpress.pl, Social media w firmach usprawniaja komunikacje i buduja relacje między pracownikami, http://socialpress.pl (05.09.2012).
} 
nication", which in a traditional internal communication is generated by e.g. excessive number of incoming e-mails" ${ }^{10}$.

Social media are mainly perceived as a way to improve the image of an organization. According to the report by GFMP Management Consultants the expected benefits include building the image of a modern organization (92\%) and integration of employees (88\%) which means the implementation of information and integration functions (figure 3.).

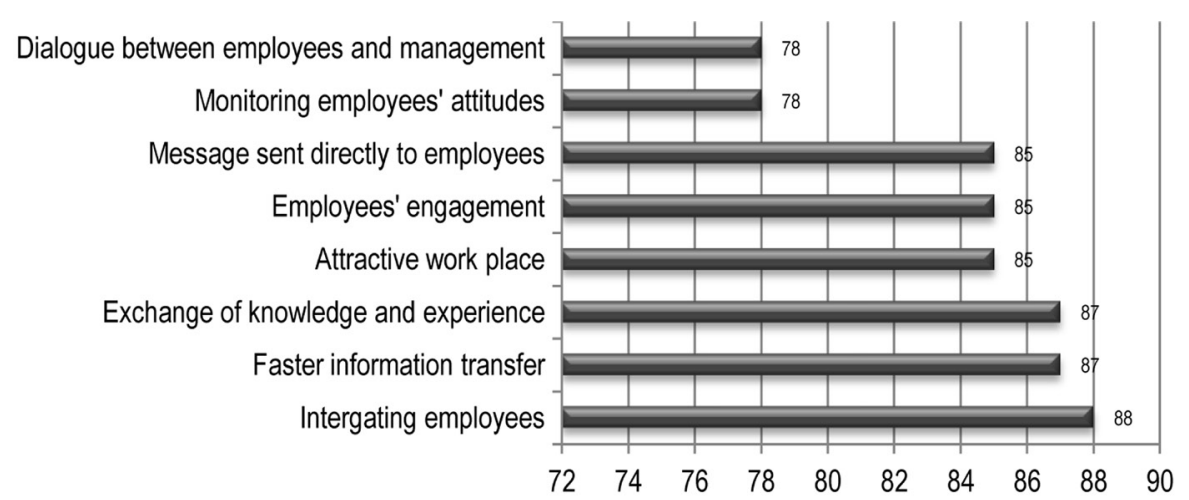

Figure 3. Expected benefits of using social media in internal communication [\%]

* Respondents could select one or several answers

Source: GFMP Management Consultants, Komunikacja wewnętrzna w Polsce 2011 - Social media i dialog w organizacji, Warszawa 2011.

\section{BENEFITS AND THREATS OF THE BRAND ENGAGEMENT IN SOCIAL MEDIA}

There are great opportunities created by brand engagement in social media, but there may also be some risks. The openness of the brand or quick feedback are just a few of the advantages of communicating with consumers. The proper use of social media can also help in crisis management. People responsible for the brand image consider social media tools the fastest and decisive in managing a crisis ${ }^{11}$.

People often use Internet communication channels to express their dissatisfaction. Making a complaint about poor service or product directly to the

${ }^{10}$ Ł. Szewczyk, Social Media w stużbie komunikacji wewnętrznej, http://media2.p1; (15.12.2012).

${ }^{11}$ M. Sobiło, Medium wszystkich ludzi, „Marketing w Praktyce”, No. 12/2011, p. 23. 
company the Internet user provides the company with valuable information about what needs to be improved. The brand, which does not remain passive when faced with consumer complaints and is able to respond to negative opinions may ultimately create a happy client. Another advantage is the fact that Internet users, who have the opportunity to express their opinion on the official forums and receive feedback, will be less inclined to spread negative views on other forums and profiles. Due to the rapid development of social media an organization has a lot more opportunities to reach consumers, but also can obtain the necessary information to design the company's development strategy. People posting on forums, blogs and social networking sites provide sales data and information about their needs and expectations. Social media sites are sometimes seen as a modern form of mailing lists. To some extent this comparison could be justified, but it should be noted that in this case, Internet users have the opportunity to reply ${ }^{12}$.

The use of social media can undoubtedly also involve risks. It could be the result of poor strategy, lack of know-how, lack of knowledge about tools, media and one's own brand, as well as the inability to control other users actively involved in shaping opinions.

On the surface, the management of social media accounts looks very simple. For this reason, many companies decide to create a profile; they upload information about their products and services and wait for the increase in the number of fans or followers. In practice, however, this strategy does not produce the desired results. There may be a few reasons for the failure. One of them is the lack of carefully designed strategy. A few years ago, there was a parallel situation when blogs started to gain popularity. Many companies chose to use this channel of communication and promotion of their brand, (sometimes just because their competitors did so). Unfortunately, due to the lack of a concrete, long-term strategy, the blogs began to fade and close down. The same applies to social networking sites today.

Another cause of failure can be treating company accounts as a virtual notice board with information about the existing and new products. To build a stronger social media impact the company must become an active member of the community, take the initiative, comment and, above all, reply to the questions asked on the profile. One can easily loose the trust of customers by leaving their questions unanswered.

In discussing the possible risks associated with the use of social media in business communication policy, one should also note the phenomenon of lack

12 C. Treadaway, M. Smith, Godzina dziennie z Facebook marketingiem, Wydawnictwo Helion, Gliwice 2011, p. 59. 
of control over content. The social media content is what users come across and what they exchange. Internet users speak spontaneously about brands, products or other people. Some of them become so popular that their opinion is more respected than the opinions of experts. In this case listening becomes more desirable than speaking. If the company manages to engage appropriate people in the discussion, the brand can gain credibility and effectively build its image.

To be successful also involves building customer relationships in a noninvasive manner, when the client is not overwhelmed with advertising and information. Non-invasive manner means showing respect for the users, so that they want to voluntarily participate in the virtual life of the company. The provided content shall compensate the user's activity on the profile by offering concrete benefits ${ }^{13}$.

The complete control over content can be maintained by designing and implementing an appropriate content management strategy. This requires an analysis of the needs of different target groups we want to reach, that is: what they want, whether their needs change depending on the circumstances and what could encourage them to post more comments about the company's activities. To ensure consistency and high-quality experience, it is important to establish the principles of editing the content. These rules determine what content the company shares with the social environment, in what manner and when.

\section{ROLE OF SOCIAL MEDIA BRAND COMMUNICATION IN THE OPINION OF RESPONDENTS}

The empirical material was collected by K. Szlasa. The study included 103 Internet users. Almost 60\% of the respondents were persons aged 19-25 years. The majority had higher education (55\%). All respondents lived in the Mazowieckie Province, had regular access to the Internet and were mostly regular Internet users ( $81 \%$ declared daily visits). The largest group of respondents used the following social networking sites - Facebook (94.2\%), nk.pl (27.2\%) and GoldenLine (33\%). It was a sample survey of public opinion. Test results are not representative, they need to be interpreted with great caution.

${ }^{13}$ A. Podlaski, Marketing spotecznościowy. Tajniki skutecznej promocji w Social Media, Wydawnictwo Helion, Gliwice 2011, p. 26. 
The surveyed Internet users expressed mostly favorable opinions about social networks and argued that they are a valuable source of information (47.3\%). In addition, almost half of the respondents were confident about their positive impact. The smallest proportion of respondents (3.9\%) trusted the information provided by traditional media (newspapers, radio and television). The majority of respondents (60\%) developed their opinion on products and services relying on their experience, and nearly $58 \%$ by consulting friends. Interactive media have more trust of the respondents compared to traditional media. Almost $43 \%$ of respondents were looking for information on the Internet and take into account the views of opinion leaders.

Still, more people search for product information on online forums (77.7\%) and on official company websites (68\%). Brand profiles on social networks were in the third position with $35 \%$ of respondents using them, ahead of information portals and corporate blogs.

Brand profiles on social networking sites are followed by $63 \%$ of respondents. They do it for two reasons: because they use the brand's products (nearly half of the respondents) or have a positive attitude towards the brand (42\%). Fewer respondents (35.9\%) use brand profiles on social networking sites to find information about products or get special offers. (figure 4.)

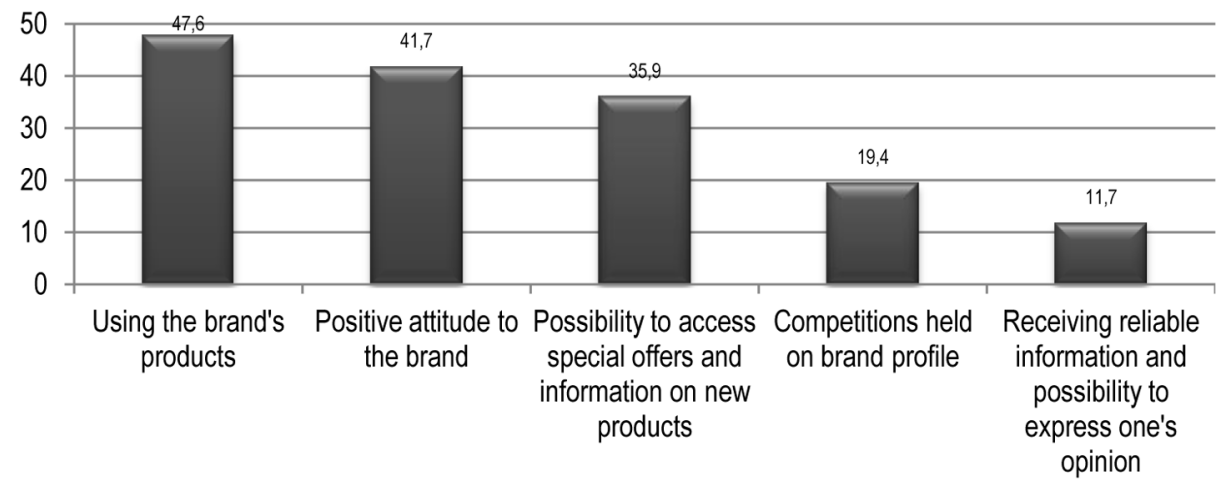

Figure 4. Reasons for following official brand profiles on social networks [\%]

* Respondents could select one or several answers

Source: own research.

The respondents also defined their expectations for the official brand profile. About $65 \%$ of people wait for the latest information to be posted on the profile, $46.6 \%$ expected a systematic and honest dialogue, but $44.7 \%$ insisted on appealing communication manner while $32 \%$ of respondents wanted to benefit from a large number of promotions and competitions. Only $7.8 \%$ 
of respondents did not expect anything from the official brand profile. As it turned out, respondents "rarely" actively followed brand profiles (47.6\% of respondents) by adding comments, liking posts, participating in competitions. Only one in four said that they "quite often" participate in the life of an online brand, and almost the same proportion (24.3\%) declared no activity in this area. Despite the high expectations of the respondents for brand profiles only $4.9 \%$ are active "very often".

As shown by the survey study, the majority of the respondents who were able to assess the credibility of content in social media found them reliable, but almost half of the respondents had no clear views on the subject. If the respondents find information on social networking sites reliable, the mere presence of the brand has a significant impact on shaping the brand image in the eyes of clients (66\%). However, one in four respondents said it was hard to say.

For the respondents, brand presence on social networking sites had only an image shaping value because the study shows that brand activity does not increase sales. About $45 \%$ of the respondents answered that brand profile activities definitely do not or rather do not increase sales. Almost $37 \%$ were unable to express views on this subject and $18 \%$ were positive about the increased sales.

It turned out, however, that negative opinions about a brand which appear on social networking sites can affect sales. Every fifth respondent declared that after reading a negative opinion they "definitely resign" from the purchase of a product, and almost half of respondents "rather resign" in such circumstances.

\section{CONCLUSIONS}

Social media in Poland are increasingly gaining popularity and trust. The users are followed by companies that want to be where the customers are. In addition, users perceive social media as a valuable source of information and, therefore, what they expect from brands is systematic communication, sharing knowledge and the latest news about products or services. The findings of our own research study show the following:

Interactive media are trusted more (43\%) than traditional media which are found trustworthy by only $4 \%$ of respondents;

Internet users search for information about a brand on online forums (78\%) and official websites (68\%). Only one third of the respondents declared to search for information on social networks. This trend may result from lim- 
ited engagement of businesses in popular social networking sites and a lack of confidence in the new ways of communication with customers;

The online activity of a brand still does not influence the purchase decision (declared by $45 \%$ of respondents), although a negative opinion about a product or service has a great impact. $66 \%$ of respondents declared resignation from the purchase of the product after reading negative reviews.

The growing popularity of new communication channels inspired a new philosophy of marketing communication. In recent years, a consumer has no longer been a passive recipient but started to be a conversation partner and inspire new promotional strategies. Having decided to use social channels in marketing and brand communication, a company must develop a long-term strategy oriented on a specific target group. However, social media and traditional channels complement each other and companies should not rely on only one of them. In order to provide consumers with complete information the corporate communication strategy must be consistent.

\section{BIBLIOGRAPHY}

Deloitte, Biznes spotecznościowy - nowa era w komunikacji biznesowej, Warszawa 2012. GFMP Management Consultants, Komunikacja wewnętrzna w Polsce 2011 - Social media i dialog w organizacji, Warszawa 2011.

Grzechowiak M., Internet Standard. Social Media 2010, International Data Group Poland SA, Warszawa 2010.

Majewski Ł., Social media zmieniaja biznes, „Nowoczesne zarządzanie”, Nr 1/2010.

Podlaski A., Marketing spotecznościowy. Tajniki skutecznej promocji w Social Media, Wydawnictwo Helion, Gliwice 2011.

Proto.pl, Przysztośc marki korporacyjnej, http://www.proto.pl (01.05.2012).

RR Communication Consulting, http://www.rrcc.pl (08.06.2013).

Sakowicz A., Kawecki A., Cyfrowo i szybko w reklamie, „Marketing w praktyce”, Nr 1/2011.

Sobiło M., Medium wszystkich ludzi, „Marketing w Praktyce”, No. 12/2011.

Socialpress.pl, Social media w firmach usprawniaja komunikacje i buduja relacje miedzy pracownikami, http://socialpress.pl (05.09.2012).

Szewczyk Ł., Social Media w stużbie komunikacji wewnętrznej, http://media2.p1 (15.12.2012).

Treadaway C., Smith M., Godzina dziennie z Facebook marketingiem, Wydawnictwo Helion, Gliwice 2011. 
